\title{
母親の胎児への愛着形成に関する研究
}

\author{
成田伸*1・前原澄子*2

\section{The Development of Maternal-Fetal Attachment During Pregnancy}

\author{
Shin Narita*1 and Sumiko Maehara*2 \\ *1 Jichi Medical School, School of Nursing \\ *2 School of Nursing, Chiba University
}

\begin{abstract}
Abstact
This study is to examine the degree to which women engage in attachment behaviors toward their unborn children. Cranley's Maternal-Fetal Attachment Scale (MFAS) was modified to Japanese version (MFAS-J2), which consists of 20 items with .87 reliability. MFAS-J2 was administered to both normal and high-risk pregnant women $(n=275)$ during gestation. All subjects were restricted to women who were having their first child, and they were between 5 and 40 weeks gestation at the time they completed the instrument. Demographic data were also gathered.

Results :

(1) Maternal-fatal attachment increased significantly from 5 to 40 weeks of gestation. Especially feeling fetal movement had positive effect on maternal-fetal attachment.

(2) Women who reported negative perception or ambivalent feeling about their pregnancy showed low attachment score. And women whose husband reported negative feeling about their pregnancy responded lower in the scale.

(3) Some negative relationships were observed between maternal-fetal attachment score and the histories of abortion and sterility.

(4) Maternal-fetal attachment showed no significant correlations to factors of threatened abortion, premature labor, and IUGR.

(5) Maternal-fetal attachment showed negative correlations to State-Trait anxiety during early pregnancies.
\end{abstract}

\section{要 旨}

女性が母親役割を獲得する過程の中で重要な部分を占める母親の胎児に対する愛着の形 成について研究した。Cranley作成のMFAS (Maternal-Fetal Attachment Scale)を翻訳 修正して作成したMFAS-J2と，不安を測定する尺度としてSTAI，基礎的情報の収集にア ンケートを用いて，275人 814 データについて分析した。対象者は全員初めて子供を持つ妊 婦で，妊娠週数は $5 \sim 40$ 週にわたった。妊娠に対するリスクを持つ妊婦と持たない妊婦の 双方を含んでいる。その結果から以下のことが明らかになった。

（1）妊婦の胎児に対する愛着は妊婦初期から形成されつつあるが，胎動初覚を契機として

${ }^{* 1}$ 自治医科大学看護短期大学 $\quad * 2$ 千葉大学看護学部 
その度合いが深まり, 妊娠 20 週以降には比較的安定した状態に至る。

（2）妊婦の妊娠に対するアンビバレントな感情や否定的な気持ち，夫の妊娠の否定的な受 け止めは，妊婦の胎児への愛着を低く押さえる。

（3）流産や不妊症治療の既往のある妊婦の愛着は，その異常の起こる危険の高い期間に， 低く押さえられる。

（4）切迫流早産などの現在進行中のリスク因子と妊婦の愛着形成との間の関係は認められ ない。

(5) 妊婦の持つ不安と妊婦の愛着との間には，妊娠の初期には有意な負の相関が認められ るが，それ以降の時期にはごく弱い相関しか認められない。

\section{I .はじめに}

妊婦の胎児に対する心理面の変化については, Deutsch $^{1)}$, Rubin $^{2)}$ によって研究され論じられ てきた。彼らに引き続き，母親が獲得すべき中 心的な役割を愛着と定義しその愛着を測定する ための試みが行われている。例宎ば，Cranley ${ }^{3)}$ は妊婦の愛着を実証的に検証しようとした一連 の研究の中で，妊婦の胎児に対する愛着を計る 尺度を開発している。

今回私は, 日本におけるこの種の研究のない ことに着目し，Cranleyの開発した用具の日本 語版の作成を試み，これを用いて次の目的で研 究を行なった。

1. 妊婦の胎児への愛着形成の過程とその形成 に影響を与える因子を明らかにする。

2 . 妊婦の胎児への愛着形成とハイリスク妊娠 との関連を明らかにする。

\section{II. 文献検 討}

妊娠は女性の人生の中で重要な出来事であり, この時期に女性は身体的な変化と共に，母親と いら新しい役割に適応しなければならない。 $\operatorname{Rubin}^{2)}$ は，女性は妊娠中に母親役割獲得の最 初の段階を通過すると考えた。彼女は妊婦が母 親になるために達成すべさ課題を 4 点あげてい るが，その一つとして“胎児との結び付きを形 成すること”を指摘した。このように，妊婦が 胎児との関係を形成していくことは，妊婦が母 親役割を獲得する過程での中心的な課題である といえよう。

愛着理論はBowlby4)によって提唱された.
一般的に愛着とは, ある人間と, 他の特定の人 間との間に形成される愛情のさずなと定義され ている. Bowlbyは, 愛着を乳児期に形成され 「人の一生を通して存続するもの」とし, 愛着 行動を「他者を求め, 他者に接近しようとする 行動」とした．そのため愛着に関する研究は， 子供の母親に対する愛着の発達について盛んに 行われてきた。それに対してKlausら5)の母子 結合Bonding の研究では, 子供が母親に抱く愛 着と共に，母親の子供に対する愛情に焦点が当 てられた。これらの研究の成果から，母親自身 も子供からの働きかけに反応し子供との結びつ きを求めていることがわかってきた。母親は, 自らの愛着要求を子供にも向けていると考兄ら れる。つまり妊婦が胎児との関係を形成するた めに胎児に向ける感情も“愛着”であると考え られる。

このような妊婦の愛着を実証的に検証しよう とする試みとして，妊婦の胎児に対する愛着を 計るための尺度の開発研究が幾つかなされてい る. $\mathrm{Cranley}^{3)}$ による「母親一胎児愛着尺度」 Maternal-Fetal Attachment Scale (以下MFAS と略)の試みがその一つである. Cranleyは, 妊婦の胎児に対する愛着を「妊婦が胎児に対し て結びつきを作り，相互に作用し合うことを表 すような行動を広く示す概念」と定義し，研究 を行った。

しかし，日本においては母親が胎児に対して 向ける感情を愛着と定義してその形成過程を実 証的に解明しようとする研究は汪とんどない。 妊婦の母親役割獲得の過程のある部分は, 文化 的・社会的な影響を免れないだろう。日本にお 
いてCranleyらと同様の試みが必要であろうと 考光る。

\section{III. 研究方法}

対象者は全員初めて子供を持つ妊婦とし，八 イリスク妊娠との関わりをみるために，妊娠に 対するリスクを持つ妊婦と持たない正常な妊婦 との双方を含んだ.今回は， $3 \sim 4$ 回の継続的 な調查を意図したことと，調査期間内に全妊娠 期間のデータ収集を目的としたために，胎動初 覚以前の妊娠初期の妊婦之胎動初覚以後の妊娠 中期の妊婦を対象とした。調查期間は, 平成 1 年 5 月 29 日から 10 月 29 日であった。首都圏にあ る $\mathrm{T}$ 産院・ $\mathrm{K}$ 病院産婦人科・ $\mathrm{M}$ 助産院の 3 施設 の外来に扔いて, 条件に合い調査への協力の承 諾の得られた妊婦に対して, 初回の調査用紙を 手渡し記入後の郵送を沶願いした. 同様に入院 中の妊婦にも依頼した. 初回の調査用紙を返送 してきた人に，2回目以降の調査用紙を郵送す ることにした.

調査には, 妊婦の愛着を測る尺度として母親 一胎児愛着尺度日本語版 (Maternal-Fetal Attachment Scale Japanese Version, 表 1, 以下 MFAS-Jと略)，不安を測定する尺度として Spilberger のSTAI (State-Trait Anxiety Inventory)を岸本ら 6)7) が翻訳作成した関学版STAI, 基礎的情報収集のためのアンケートを組み合わ せたものを用いた。 またハイリスク因子の有無 をみるためにカルテからの情報収集を追加した。

\section{IV ．母親一胎児愛着尺度日本語版について}

本研究で使用したMFAS-Jは，1981年に Cranley ${ }^{3)}$ が作成したMFASをCranley の承諾 を得て, 研究者自身が翻訳・修正して作成した ものである. CranleyのMFASは妊婦が胎児と
の関係を作っていくときに示す行動を表す24項 目からなり, 回答はリカートタイプの 5 つの選 択肢からなっている．得点は 1 点から 5 点まで の間に分布し，得点が高い汪ど愛着が高いこと を示す.MFASの妥当性は文献と臨床的な経験 によって打ち立てられて抢り，信頼性はCronbach

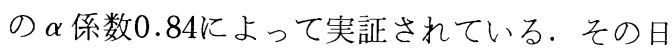
本語版であるMFAS-J作成の過程では，妊娠 経験のある母性看護の専門家や非専門家の意見 をもとにして，日本人の妊婦の感覚に合うよう な表現に修正しており，妊婦31人に対して行っ

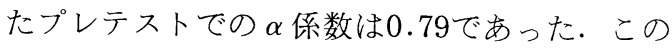
質問紙には胎動が感じられないと必然的に 1 点 になってしまら項目が 4 つ含まれている，妊娠 全期間を対象にする今回の研究にはこの項目は 支障が大きいため，その 4 項目を削除したMFASJ2を最終的な分析に用いた. MFAS-J2のCranley のMFASとMFAS-J2とを比較して同程度の妥 当性・信頼性が維持されていると判断し, 研究 に使用した。

\section{V. 結果}

初回の調查用紙の配布総数は436, 回収数 276 , 回収率は $63.3 \%$, 最終的な回収数は初回を含め て908, 有効データ数は妊婦 275 人の 814 たたた. 平均回答数は 3.0 回, 回答時の妊婦週数は $5 \sim 40$ 週であった. 対象となった妊婦の概要は, 平均 年齢 27.1 才 $(17 \sim 40$ 才, $\mathrm{SD}=4.1)$, 学歷は, 中 学卒 9 人 $(3.2 \%)$, 高校卒 148 人 $(53.8 \%)$, 短大 大学卒 73 人 $(26.5 \%)$, 不明 45 人 $(16.4 \%)$ であっ た。その夫，あるいは胎児の父親（以下夫と略） の平均年齢は, 30.3 才 $(18 \sim 48$ 才, $\mathrm{SD}=5.2)$ で あった. 今回使用したMFAS-J2の有効データ 数814に対する $\alpha$ 係数は 0.87 (MFAS-Jでは0.89) であった。

\section{表 1 母親一胎児愛着尺度日本語版（一部を示した）}

\begin{tabular}{|c|c|c|c|c|c|c|}
\hline 1 & $\begin{array}{l}\text { 私はお腹の中の赤ちゃんに話しかけま } \\
\text { す. }\end{array}$ & $\begin{array}{l}\text { いつもそ } \\
\text { らです }\end{array}$ & $\begin{array}{l}\text { だいたい } \\
\text { そらです }\end{array}$ & $\begin{array}{l}\text { ときどき } \\
\text { そうです }\end{array}$ & $\begin{array}{l}\text { たまにそ } \\
\text { うです }\end{array}$ & $\begin{array}{l}\text { 一度もあ } \\
\text { りません }\end{array}$ \\
\hline 2 & $\begin{array}{l}\text { 私は妊娠したことで生じるわずらわし } \\
\text { さや面倒くささむ, すべて価值のある } \\
\text { ことだと思います. }\end{array}$ & $\begin{array}{l}\text { いつもそ } \\
\text { らです }\end{array}$ & $\begin{array}{l}\text { だいたい } \\
\text { そらです }\end{array}$ & $\begin{array}{l}\text { そきどき } \\
\text { そうです }\end{array}$ & $\begin{array}{l}\text { たまにそ } \\
\text { うです }\end{array}$ & $\begin{array}{l}\text { 一度もあ } \\
\text { りません }\end{array}$ \\
\hline 3 & $\begin{array}{l}\text { 私は赤ちゃんがお腹の中で動くのを見 } \\
\text { たり感じたりするのが楽しい. }\end{array}$ & $\begin{array}{l}\text { いつもそ } \\
\text { うです }\end{array}$ & $\begin{array}{l}\text { だいたい } \\
\text { そうです }\end{array}$ & $\begin{array}{l}\text { ときどき } \\
\text { そうです }\end{array}$ & $\begin{array}{l}\text { たまにそ } \\
\text { らです }\end{array}$ & $\begin{array}{l}\text { 一度もあ } \\
\text { りません }\end{array}$ \\
\hline
\end{tabular}


データの統計処理には, 同じ妊婦のデータで あっても妊婦週数によって異なったデータとし て扱い，のべ数814を使用した. 統計処理には, 統計プログラムパッケージ「HALBOU」を用 い，有意差の検定には $\mathrm{t}$ 検定と $\mathrm{F}$ 検定を用い， 有意水準は $5 \%$ 未満とした。 また妊婦の愛着と それに関わる因子との関係をみるために，妊娠 週数を, 妊娠 $5 \sim 15$ 週, 16 23週, $24 \sim 31$ 週, 32〜40週の 4 群に分けて(胎動初覚との関係で はさらに16〜19週，20〜23週に分割) 分析した.

\section{1. 妊娠の経過と愛着形成との関係}

妊婦の胎児に対する愛着が妊娠週数の経過に 伴って変化するかをみるために，MFAS-J2と 妊娠週数との相関をみた。相関図と回帰直線を 図 1 に示した.MFAS-J2と妊娠週数との間に は，弱いが有意の相関がみられた。

次に胎動初覚と愛着との関係について, 妊娠 16〜19週，20〜23週にわけて分析した(表 2 ).

どちらの週数でも胎動を感じている妊婦の得点 の方が，まだ感じていない妊婦の得点よりも有 意に高かった。

\section{2. 対象者の属性と愛着との関係}

アンケートから得られた妊婦の年齢・職業・ 学歴・経済状況・妊娠の計画性・妊婦の乳児の 世話経験・夫の家事への協力度・相談相手につ いて愛着との関係を分析したが，有意な関係は 認められなかった。

\section{3. 弤婦および夫の妊娠に対する気持ちと愛着 之の関係}

妊婦の妊娠の受け止めを「非常に嬉しい」 (Positive 群, P 群と略),「どちらかといえば 嬉しい」(Rather Positive群, R-P群と略), 「どちらかといえば困った」「非常に困った」 (Negative群, N群と略)の 3 群に分けて分析 した結果を図 2 に示した。妊娠全期間を通じて 3 群間に有意な差があり, P 群の得点が最も高 く推移するといら結果であった.

また夫の妊娠の受け止めと妊婦の愛着との関 係について, 妊婦の妊娠の受け止めと同様に $\mathrm{P}$ 群, R-P群, N 群の 3 群に分け, 分析した(図 3 ). 妊娠 $16 \sim 23$ 週， $24 \sim 31$ 週の間で 3 群の得 点間に有意な差があり, 妊娠全期間を通じて N

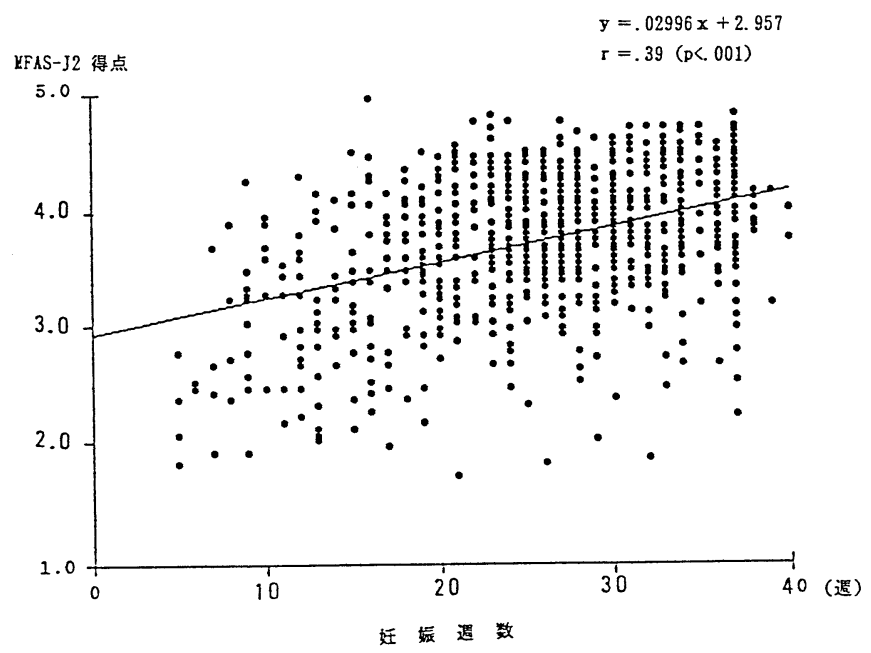

図 1 妊娠経過に伴うMFAS-J2得点の推移

表 2 胎動初覚と愛着との関係

\begin{tabular}{|c|c|c|c|c|c|c|}
\hline & \multicolumn{3}{|c|}{ 妊娠 $16 \sim 19$ 週 } & \multicolumn{3}{|c|}{ 妊娠20～23週 } \\
\hline & $\mathrm{N}$ & Mean & SD & $\mathrm{N}$ & Mean & SD \\
\hline 胎動をまだ感じていない妊婦 & 40 & $3.367 *$ & 0.36 & 8 & $3.337 *$ & 0.832 \\
\hline 胎動をすでに感じている妊婦 & 31 & $3.67-^{*}$ & 0.503 & 111 & $3.81]^{*}$ & 0.462 \\
\hline
\end{tabular}

$* \mathrm{p}<0.05$ 


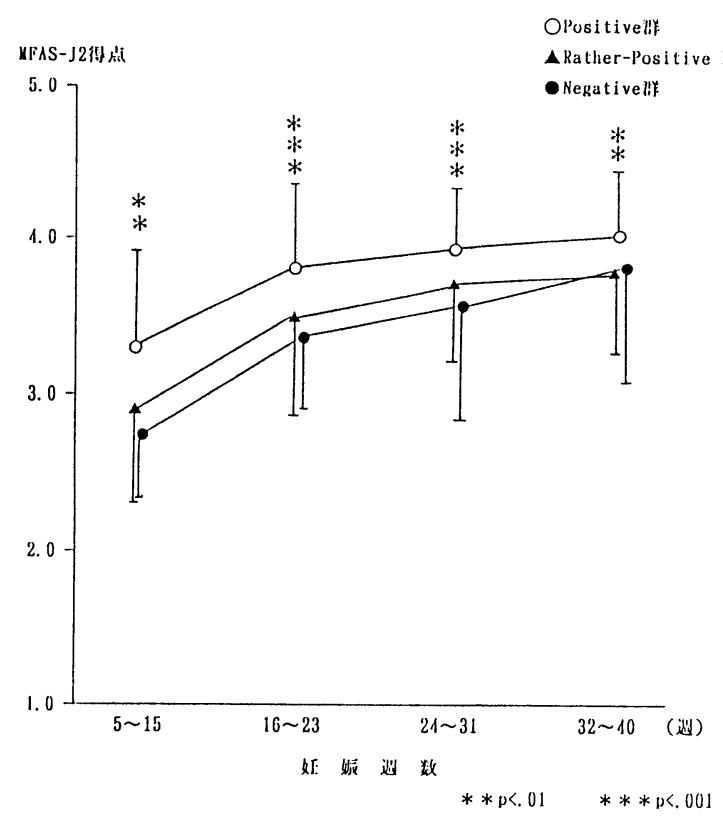

図 2 妊娠の妊娠の受け止めと愛着との関係

群の得点が最も低いという結果であった.

\section{4. ハイリスク妊娠と愛着との関係}

自然流産の既往の有無と愛着との関係につい て分析したところ，妊娠 $5 \sim 15$ 週では自然流産 の既往のある妊婦の得点はない妊婦の得点より も有意に低く，妊娠 $24 \sim 31$ 週で，32〜40週では 反対に有意に高いといら結果であった(図 4 ).

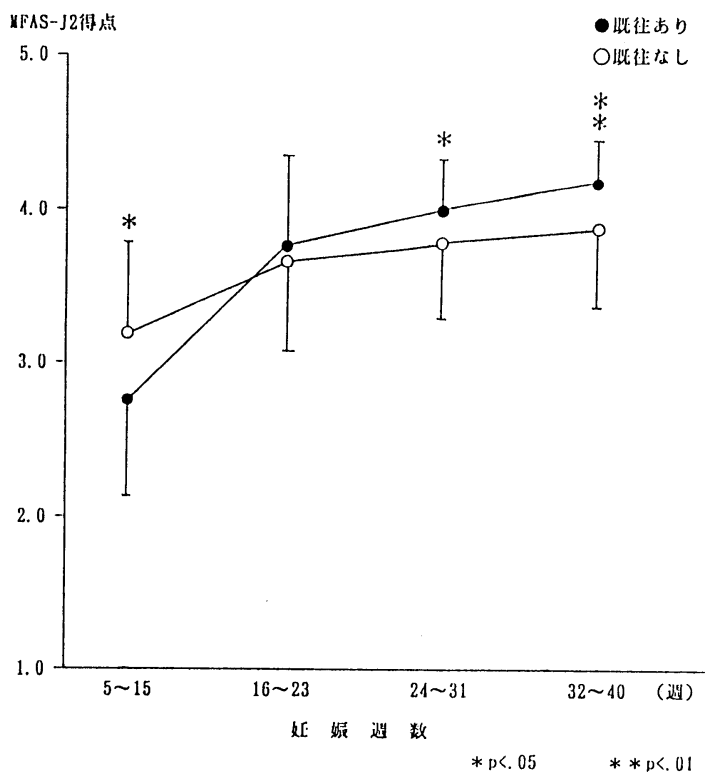

図 4 自然流産の既往の有無と愛着との関係

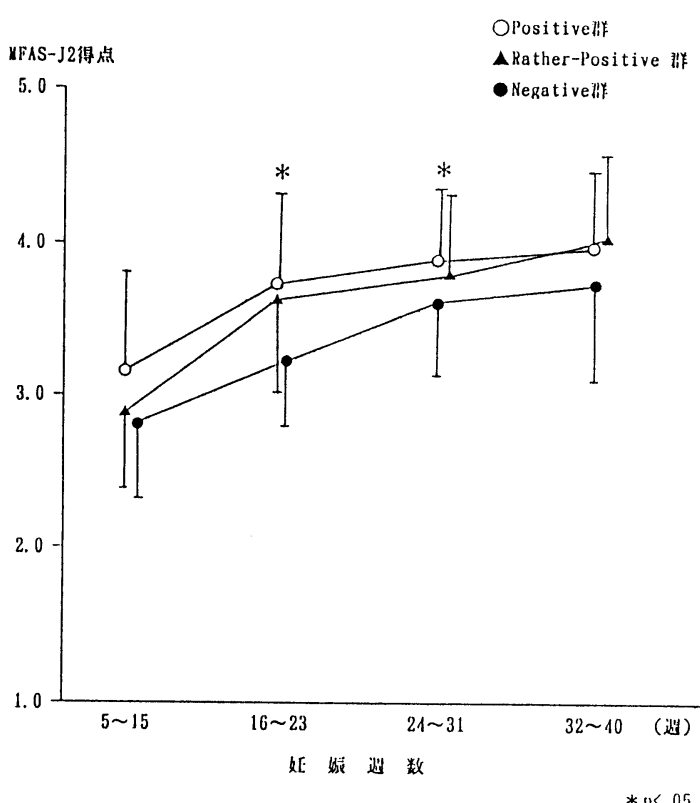

図 3 夫の妊娠の受け止めと愛着との関係

不妊症治療の既往と愛着との関係を図 5 亿示し た。不妊症治療の既往のある妊婦では，自然流 産の既往の妊婦のような妊娠初期に低いという 傾向はみられなかったが，末期には不妊症治療 の既往のない妊婦より既往のある妊婦のほうが 高くなっていた。

調査時点で切迫流早産の治療を受けている妊

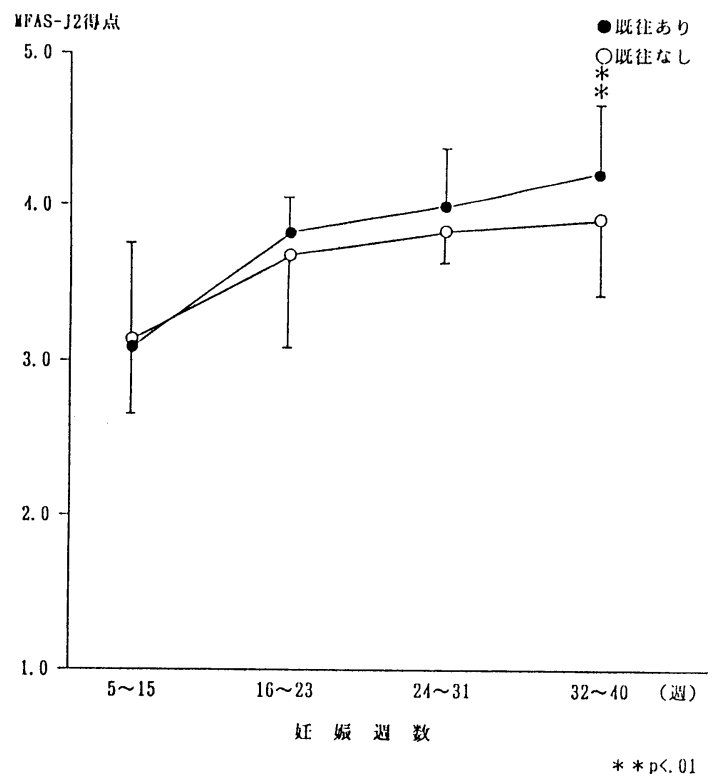

図 5 不妊症治療の既往の有無と愛着との関係 


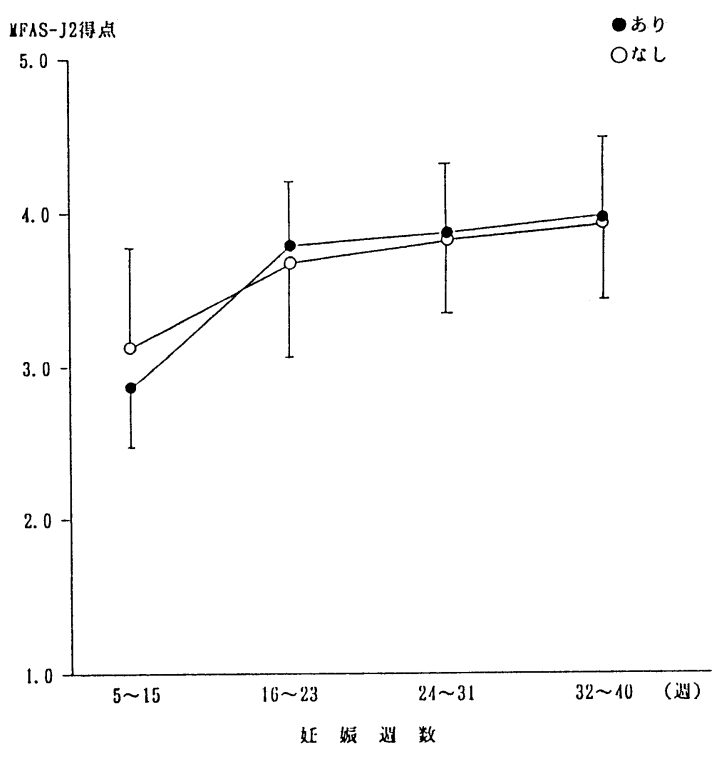

図 6 切迫流早産の有無と愛着との関係

婦の愛着について分析した結果を, 図 6 に示し た. 切迫流早産の場合, 愛着の得点に差はみら れなかった．胎児に対する不安が高いと思われ る子宮内胎児発育不全の診断のあった妊婦で分 析したところ，妊娠24３1週で診断ありの妊婦 の愛着の平均得点 $3.82(\mathrm{SD}=0.58, \mathrm{~N}=5)$, 診 断なしの妊婦の平均得点 $3.82(\mathrm{SD}=0.49, \mathrm{~N}=$ 314)であり，両群に有意な差はなかった。32〜 40週でも同様であった（診断あり群，平均 3.78 , $\mathrm{SD}=0.58, \mathrm{~N}=11 /$ なし群, 平均 $3.93, \mathrm{SD}=0.50$, $\mathrm{N}=207$ ) .

\section{5. 不安と愛着との関係}

妊婦の持つ不安をSTAIを用いて測定し，愛 着との関係をみた (表 3 ). 特性不安と愛着との 間には妊娠 $5 \sim 15$ 週で有意だがごく弱い負の相 関が認められた以外は，強い関係は認められな かった. 状態不安と愛着との間には全妊娠期間 を通じて弱いが有意の負の相関があった。この
関係は妊娠 5 〜 15 週において特に強く認められ た。

\section{VI. 考察}

\section{1. 妊娠の経過と愛着形成との関係}

妊婦の胎児に対する愛着が，妊娠週数に伴っ て変化するといら報告は, Leifer ${ }^{8)}$, Heidrich $^{9)}$ らによって行われている. 今回の研究でも，妊 娠週数と愛着との間には有意な正の相関が認め られた.このことは，妊婦の胎児に対する愛着 が妊娠の進行にともなって増加するといらこと を実証しているといえる。

Leif er $^{8)}$ は，妊婦の愛着形成のプロセスを 3 パターンに分析している. 妊婦の愛着が妊娠中 を通じて低く妊娠末期でもそれは変わらないパ ターン，妊娠初期には胎児に対して親密さを感 じていないが，胎動初覚を契機として胎児への 愛着が高まっていくパターン，胎児への愛着は 妊娠初期からあり，その後より深まり，末期に は胎児としっかりした関係が築かれているパター ンの 3 つである. 図 1 では，妊娠 20 週くらいま での愛着得点の方がそれ以降の愛着得点よりも ばらつきが大きい. Leiferの 3 パターンでも明 らかなよらに，胎動が感じられない時期の妊婦 の愛着にはかなり個人差があるが，多くの妊婦 が胎動を感じるようになると愛着得点は全体的 に上昇し，ばらつさは小さくなる。市た，胎動 を感じることが愛着を高める契機となることは， 胎動を感じている妊婦と感じていない妊婦とが 混在している妊娠16〜19週，20～23週について の結果でも明らかである。この結果からは，ど ららの週数でも愛着を感じている妊婦の得点の 万が，感じていない妊婦の得点よりも有意に高 く，胎動を感じることが愛着を高める方向へ影 響しているといえる。

表 3 不安と愛着との関係

\begin{tabular}{|l|ll|ll|}
\hline & \multicolumn{2}{|c|}{ 特性不安と愛着 } & \multicolumn{2}{c|}{ 状態不安と愛着 } \\
\hline 妊娠 $5 \sim 15$ 週 & $\mathrm{r}=-0.261 \quad \mathrm{p}<0.05$ & $\mathrm{r}=-0.449$ & $\mathrm{p}<0.001$ \\
\hline 妊娠16 23週 & $\mathrm{r}=-0.079$ & $\mathrm{r}=-0.173$ & $\mathrm{p}<0.05$ \\
\hline 妊娠 $24 \sim 31$ 週 & $\mathrm{r}=-0.046$ & $\mathrm{r}=-0.222$ & $\mathrm{p}<0.001$ \\
\hline 妊娠32 40週 & $\mathrm{r}=-0.123$ & $\mathrm{r}=-0.172$ & $\mathrm{p}<0.05$ \\
\hline
\end{tabular}


つまり胎児への愛着は受胎後早期から形成さ れつつあるが，胎動初覚を契機としてその度合 いが深まり，妊娠 20 週以降には比較的安定した 状態に至るといえる。

\section{2. 妊婦および夫の妊娠に対する気持ちと愛着 との関係}

妊婦の妊娠の受け止めと子供への愛着との関 係は，今まで分娩後について多く検討されてき た. Robson ${ }^{10)}$, Freming ${ }^{11)} ら の$ 研究でも妊娠 の受容は愛着形成にとって重要な因子とされて いる. 今回の研究でも，妊娠の受け止めがよい 妊婦は妊娠全期間を通じて最も高い得点を示し， 今まで分娩後についての研究でいわれてきたこ とが実証された。つまり，妊娠を受容すること は胎児への愛着を形成するための重要な因子で あるといえる。

Kemp ${ }^{13)}$ らによって妊娠の計画性と胎児への 愛着との関係が検討されたが差はみられなかっ た。 今回も, 妊娠の計画性と愛着との間に関係 はみいだせなかった、今回のアンケートの回答 を詳しく検討すると，非計画的な妊娠だとして いても単に $1 ・ 2$ か月予定より早いだけだとい ら妊婦で, 妊娠自体は嬉しいとする人も多くみ られた。一方，計画的な妊娠だとしながらも， 妊娠の受け止めが「どちらかといえば嬉しい」 という回答の妊婦もいた。 この回答は妊娠した ことを純粋には喜べない心境を反映していると も取れ，妊娠に対するアンビバレントな感情の 存在を表しているものと思われる，妊娠の受容 と胎児への愛着との関係が認められるのに対し て，妊娠の計画性と愛着との間に関係がないの は，計画的な妊娠であることと妊娠の受容とは 関係がないことの証明であろう。妊娠の受容に 問題があり，受容が困難であることの原因追究 とその看護方法の究明の必要性があるだろう。

Rubin ${ }^{2)}$ は, 妊婦の発達課題として, 重要な 他者に胎児を受け入れてもららことをあげてい る. 今回の研究では, 夫の妊娠の受け止めが肯 定的である方が妊婦の胎児への愛着が高いこと がわかった。 夫は妊婦にとって胎児を受け入れ て帛しい重要な他者であり，妊婦の胎児への感 情に重要な影響を及ぼすといえる。Cranley ${ }^{13)}$ は, 強いソーシャルサポートを持つ妊婦の胎児
への愛着が高いと述べている．妊婦にとっての ソーシャルサポートの第一のリソースは夫であ り, 夫の受け止めが妊婦の愛着に影響するとい う今回の結果はこのCranleyの研究を支持する といえよう。

\section{3. ハイリスク妊娠と愛着との関係}

Floyd ${ }^{14)}$ は，以前の妊娠が不幸な結果に終わっ ている妊婦は, 妊娠を現実的に受容しにくく, 胎児のことを具体的に表現することも難しいと 述べている. 今回の研究では, 過去に自然流産 の既往のある妊婦の場合，妊娠初期の胎児への 愛着が有意飞低かった。このことは前述した研 究で述べられているように，妊娠の継続が確実 になるまでの間，妊婦の胎児への愛着形成が低 く押さえられていたことを表すものであろら． またHeidrich ${ }^{9)}$ は，羊水穿刺による遺伝診断前 には低かった妊婦の愛着得点が，胎児の異常の ないことが確かめられた後には，他の異常のな い妊婦と同じレベルをで回復したと報告してい る.今回の結果からも，流産の危機が去った妊 娠中期には初期にあった既往のない妊婦之の差 がなくなっており，Heidrichの結果と同じとい えよう。

流産の既往のある妊婦の胎児への愛着得点は， 妊娠中期以降は逆転し既往のない妊婦の得点よ りも高くなっている。このことは不妊症治療の 既往のある妊婦でもい光，妊娠末期において愛 着得点が有意に高くなっている，長野 ${ }^{15)}$ は, 過去に流産経験を持ち，今回も妊娠異常のみら れる群は「妊娠」や「母親になること」に高い 価值を置いていると報告している．妊娠中期以 降の愛着得点が有意に高いのは，流産や不妊症 を経験した妊婦の汪らが初めて妊娠した人以上 に，子供を欲しいといら気持ちを強く持ち子供 を持つことに高い価値を置いていることを示す ものといえる。

今回の結果では，切迫流早産・子宮内胎児発 育不全の各症状・診断と愛着との間に関係はな かった. Kemp ${ }^{12)}$ は，妊娠28３9週のハイリス ク妊婦について研究した結果，リスクのある妊 婦の愛着得点とリスクのない妊婦の愛着得点と は差がなかったと報告している，そしてその原 因として，妊娠末期になっているため胎児の生 
存に対して楽観的になっていたためではないか と述べている. 今回の研究でも, 流産の既往の あった妊婦では, 妊娠初期の妊娠の継続がまだ 不確実な時期には胎児への愛着が低かった。し かし, 現在存在するリスクとして胎児生存への 危険度が最も高いと考光られる切迫流産や子宮 内胎児発育不全の診断のあった妊婦においても 愛着得点に差はなかった。

この理由としては, 質問紙を記入してもらう という研究方法上, 流産の可能性が非常に高い 妊婦や，嘔吐などの重症な症状などの身体的な リスクがより高い妊婦が，除外されてしまうと いらことが考兄られる. 一方, Kempの結果で もハイリスク妊娠と愛着との関係が認められな かったことを考光ると, 現在進行中のリスク因 子と過去にあった不幸な結果といらリスク因子 は異なった影響を与えるのかもしれない。この 点については, 研究方法・対象・リスクの選択 などを含めて今後とも研究が必要である.

\section{4. 不安と愛着との関係}

Cranley ${ }^{13)}$ は, STAIを用いて愛着と不安と の間には関係がなかったと報告している。それ に対してGaffney ${ }^{16)}$ は状態不安では愛着得点 との間に弱いが有意な負の関係があったという. 今回の結果では, 状態不安と愛着得点との間に は弱いが有意の負の関係がみられ, 妊娠 $5 \sim 15$ 週にその関係はやや強く認められた. Gaffney の結果と今回の結果とを合わせて考学ると，妊 婦の持つ不安の愛着に対する影響は妊娠初期の 方が大きいといえよう。

\section{VII. 結論}

本研究で以下のことが明らかになった.

(1) 妊婦の胎児に対する愛着は妊娠初期から形 成されつつあるが，胎動初覚を契機としてそ の度合いが深まり，妊娠 20 週以降には比較的 安定した状態に至る.

（2）妊婦の妊娠に関するアンビバレントな感情 や否定的な気持ち，夫の妊娠の否定的な受け 止めは，妊婦の胎児への愛着を低く押さえる.

（3）流産や不妊症治療の既往のある妊婦の愛着 は，その異常の起こる危険の高い期間に，低 く押さえられる。
（4）切迫流早産などの現在進行中のリスク因子 と妊婦の愛着形成との間の関係は認められな い.

（5）妊婦の持つ不安と妊婦の愛着形成との間に は, 妊娠の初期には有意な負の相関が認めら れるが，それ以降の時期にはごく弱い相関し か認められない。

\section{謝辞}

本研究にあたり，長期に渡りご協力頂けました 対象者の皆様と, 貴重なご助言を頂きました千葉 大学母性看護学講座の皆様に深く感謝致します.

\section{引用文献}

1 ) Deutsch, H.：䀣田克躬, 原 百代訳：母性 のきざし，母性の心理 1 ， 日本教文社， 1964 .

2) Rubin, R.: Maternal tasks in pregnancy. Maternal-Child Nursing Journal, 4 (3), 143-153, 1975.

3 ) Cranley, M.S. : Development of a tool for the measurement of maternal attachment during pregnancy . Nursing Research, 30 (5) , 281-284, 1981.

4 ) Bowlby, J. : 黒田実郎, 大羽 蓁, 岡田洋 子訳 : 母子関係の理論 (1)愛着行動, 岩崎学 術版社, 1976 .

5 ) Klaus, M.H., et al.: Importance of the first post-partum days. New England Journal of Medicine, 286 (9) , 460-463, 1972.

6 ) 岸本陽一, 他: STAIの標準化 (1)一信頼性の 検討, 日本心理学会第46回大会発表論文集, $311,1982$.

7 ) 岸本陽一, 他 : STAI の標準化 (2)一妥当性の 検討, 日本心理学会第47回大会発表論文集, $619,1983$.

8 ) Leifer, M.: Psychological changes accompanying pregnancy and motherhood. Genetic Psychology Monographs, 95, 55-96, 1977.

9 ) Heidrich, S.M., et al.: Effect of fetal movement, ultrasound scans, and amniocentesis on maternal-fetal attachment. Nursing $R e-$ search, 38 (2), 81-84, 1989.

10) Robson, K.S., et al.: Patterns and determi- 
nants of maternal attachment, Journal of Pediatrics, 77, 970-985, 1970.

11) Freming, A.S., et al. : Postpartum adjustment in first time mothers: Relations between mood, maternal attidude, and mother-infant interactions. Developmental Psychology, 24 (1) $71-81,1988$.

12) Kemp, V.H., et al.: Maternal attachment in normal and high-risk pregnancies. Journal of Obstetric, Gynecologic, and Neonatal Nursing, 16 (3) , 179-184, 1987.

13) Cranley, M.S. : The impact of perceived stress and social support on maternal fetal attach- ment in the third trimester. Unpublished doctoral dissertation. University of WisconsinMadison, 1979.

14) Floyd, C.C.: Pregnancy after reproductive failure. American Journal of Nursing, 81 (11), 2050-2053, 1981 .

15）長野正美：妊娠・出産と母性意識. イメージ 調査による分析，聖心女子大学卒業論文，1977.

16) Gaffney, K.F.: Maternal-fetal attachment in relation to self-concept and anxiety. Maternal-Child Nursing Journal, 15 (2), 91-101, 1986 . 